\title{
骨材間隙状態を考慮した アスファルト混合物の配合指標に関する一検討
}

\author{
小澤光一 $^{1} \cdot$ 國分修一 ${ }^{2} \cdot$ 小梁川雅 $^{3}$ \\ ${ }^{1}$ 正会員 大林道路株式会社 技術研究所（テ336-0027 埼玉県浦和市沼影 2-12-36) \\ ${ }^{2}$ 正会員 工博 大林道路株式会社 技術研究所（广336-0027 埼玉県浦和市沼影 2-12-36) \\ ${ }^{3}$ 正会員 工博 東京農業大学地域環境科学部生産環境工学科（テ156-0054 東京都世田谷区桜丘 1-1-1）
}

アスファルト混合物の特性はアスファルトモルタル量やフィラービチューメン量に大きく影響されること がよく知られているが，連続粒度混合物の他に特殊混合物の使用実績か増加している現在では，今まで以上 にアスファルトモルタルやフィラービチューメンを意識した配合設計が必要であり, 全ての混合物に対して アスファルト舗装要綱に示される配合設計法を適用するには限界があるものと考えられる. 本文は, 粗骨材 間隙容積に対するアスファルトモルタル容積比と細骨材間隙容積に対するフィラービチューメン容積比を配 合指標として定義し，これによって混合物の特性が適切に表示できるかを検討したものである. その結果， 本配合指標は密粒度アスコンの特性值の変化傾向を適切に表現できることか雄認された。

Key words : hot asphalt mixture, mix design, strength, durability, surface characteristics

\section{1. はじめに}

現在，我国で一般的に行われている加熱アスファ ルト混合物の配合設計は, 骨材の合成粒度が定めら れた範囲に収まるように使用骨材の配合割合を調整 し，合成された骨材にアスファルト量を変化させて 供試体を作製し、マーシャル試験を実施してアスフ アルト量を決定する方法である ${ }^{1)}$.ここの時，アスフ アルト量はマーシャル試験における特性值が基準の 範囲に有る共通部分の中央值として定める。この方 法は, 昭和 36 年に発行された「アスファルト舗装 要綱」 ${ }^{2)} に$ 紹介されて以来, 日本道路協会が行った 混合物の実態調査によって混合物の種類每に平均值 $\pm 2 \sigma$ として骨材粒度範囲を修正し，さらにマーシ ヤル諸基準を満たすアスファルト量の平均をもって アスファルト量としていたのを共通範囲の中央をも ってアスファルト量とするなどの修正が加えられ現 在に至っている。世界におけるアスファルト混合物 に関する配合設計方法の変遷や我国におけるアスフ アルト舗装要綱の配合設計方法の修正事情は参考文 献 3)4)に詳述されているが, 現在我国で用いられ ている加熱アスファルト混合物の配合設計方法は骨
材粒度一混合物空隙一混合物の強度特性の関係を統 計データに基づいて経験的に定めている伝統的な方 法を踏襲しており, 合成粒度が一定の場合でもアス ファルト量を変化させると骨材間隙に占めるアスフ アルトモルタル量と細骨材間隙に占めるフィラービ チューメン量が変化する結果となっている.しかし, これまで多くの研究者がアスファルト混合物の諸特 性は骨材間隙とフィラービチューメンの品質に大き く影響されるとしており ${ }^{5) 6)}$ ，また，改質アスファ ルトが普及して一般的な連続粒度混合物の他にも大 粒径アスファルト混合物，SMA，ゴム粒子を混入 した混合物, 排水性混合物, O G F C 用混合物など の使用実績も増えてきている現在では，今まで以上 に粗骨材間隙に対するアスファルトモルタル量や細 骨材間隙に対するフィラービチューメン量およびフ イラービチューメンの品質を意識した配合設計が必 要であり，これらの混合物に対して従来の配合設計 方法を適用するには限界があるものと考えられる。

本研究は, 以上の現状を鑑み, 物理的な意味を持 たせた新しい配合因子を提案すること，提案した配 合因子が混合物の強度, 耐久性および表面性状を表 す各試験項目の変化傾向を適切に示しているか否か 
表-2.1 使用材料

\begin{tabular}{|c|c|c|c|c|c|c|}
\hline \multicolumn{2}{|c|}{ 項目 } & \multicolumn{2}{|c|}{ 6号砕石 7 号砕石 } & 粗目砂 & フィラー & バインダ \\
\hline \multicolumn{2}{|c|}{ 材質 } & \multicolumn{2}{|c|}{ 硬質砂岩 } & 川砂 & 石灰岩 & 자ア ス60/80 \\
\hline \multirow{3}{*}{ 比重 } & 見掛 & 2.687 & 2.685 & 2.685 & 2.762 & \multirow{3}{*}{1.030} \\
\hline & かさ & 2.629 & 2.588 & 2.616 & - & \\
\hline & 表乾 & 2.650 & 2.624 & 2.640 & $\longrightarrow$ & \\
\hline \multicolumn{2}{|c|}{ 吸水率 $(\%)$} & 0.82 & 1.39 & 1.00 & $\longrightarrow$ & \\
\hline \multirow{6}{*}{$\begin{array}{l}\text { 粒 } \\
\text { 度 }\end{array}$} & 19.0 & 100 & & & & \\
\hline & 13.2 & 99.6 & 100 & & & \\
\hline & 4.75 & 4.8 & 99.3 & & & \\
\hline & 2.36 & 0.1 & 2.1 & 100 & & \\
\hline & 0.6 & & 0.2 & 44.1 & & \\
\hline & 0.3 & & & 25.1 & 100 & \\
\hline \multirow[t]{2}{*}{ (\%) } & 0.15 & & & 7.7 & 95.3 & \\
\hline & 0.075 & & & 1.5 & 76.8 & \\
\hline
\end{tabular}

を検討することを目的とする.

\section{2. 実験概要}

\section{(1) 材料}

実験に使用した材料を表-2.1 に示す．骨材は 6 号砕石， 7 号砕石および粗目砂をそれぞれ 13.2 $4.75 \mathrm{~mm}, 4.75 \sim 2.36 \mathrm{~mm}$ よび $2.36 \sim 0 \mathrm{~mm}$ のサイズ に調整したものを用いた。

\section{（2）配合設計指標 Am および Ap}

舗装用アスファルト混合物は曲げ強度，耐流動性， 耐摩耗性, 耐水性に優れ, 滑り抵抗や平坦性が確保 できることが必要である。これらの特性は，主にア スファルトモルタルの量とフィラービチューメンの 品質が影響し，一般的にアスファルトが多いアスフ アルトモルタルを用いる場合に耐摩耗性, 而水性が 向上し，アスファルトモルタルが少ないほど耐流動 性, 滑り抵抗性が向上するものと考えられる。ここ で提案する配合設計指標は，これらの状況を把握し 易いことを第一に考え，転圧コンクリートの配合設 計方法 ${ }^{7)}$ 参考に, 粗骨材間隙に対するアスファル トモルタル量の容積比を Am ，細骨材間隙に対する フィラービチューメンの容積比を $\mathrm{Ap}$ として次式の とおり定義した。

$$
\begin{aligned}
& A \mathrm{~m}=\frac{\text { アスファルトモルタルの容積 }}{\text { 粗骨材間隙容積 }} \\
& \mathrm{Ap}=\frac{\text { フィラービチューメンの容皘 }}{\text { 細骨材間隙容積 }}
\end{aligned}
$$

\section{（3）実倹方法}

一般的なアスファルト混合物の Am および Ap が どのような範囲に有るかを知るために，まず，実験 に用いる 6 号および 7 号砕石の最密充填配合を求め, 合成した粗骨材, 細骨材およびフィラービチューメ ンの各々単体について供試体を作製して密度を測定 した. 最密充填配合割合を求める場合と合成した粗 骨材および細骨材の密度を求める場合, アスファル トによる湿潤の有無が骨材の締固め程度に影響を与 えることを考虑して各々骨材重量に対して 2 および 7\%のアスファルトを混合してマーシャル供試体作 製方法と同様な方法で両面 50 回突き固めて供試体 を作製した。 また，フィラービチューメンの密度を 求める場合, マーシャル供試体作製温度と同一に加 熱したフィラーとアスファルトを保温装置付きのミ キサー中で 5 分間混合し, $\phi 50, \mathrm{~h} 100$ の型枠に流し 込んで供試体を作製した. 次に, 最密充填粗骨材, 細骨材，フィラーを用いてアスファルト舗装要綱に 準じて配合設計を行い, 密粒度アスコン (13) の中央 粒度になる細粗骨材とフィラーの配合率を求め, 混 合物に対する内割り重量比で 5.0 7.0\%にアスフ アルト量を変化させ, 突き固め回数を両面 50 回と してマーシャル供試体を作製した. アスファルト量 はマーシャル特性値の諸基準を満たす範囲の中央値 として求めた.

Am および Ap がアスファルト混合物の配合設計 指標となり得るか否かの検討は, Am および Ap が アスファルト混合物の強度, 耐久性, 表面性状を表 す各試験項目において特性値の変化傾向を適切に示 すことができるか否かによって判定されるので, Am および $\Lambda \mathrm{p}$ を变化させて作製した供試体について表 - 2.2 に示す各試験を行った。各試験に用いる供試 体の作製および試験方法は表-2.2 に示す各規準に 従っている。 また, Am および Ap を変化させた各 混合物の 6 号砕石と 7 号砕石の割合は上述の最密充 填配合割合とし，フィラービチューメンに占めるフ ィラーとアスファルトの割合 $(\mathrm{F} / \mathrm{A})$ は, アスファル 卜舗装要綱による密粒度アスコン(13) の配合設計で 得られたものと同一に設定した。実験に用いた混合 物の配合を表-2.3に示す.

\section{（4）ラベリング試験}

舗装試験法便覧法では摩耗促進にサイドチェーン (JIS G 4051 S35C) を用いるとしているが，本実験 では, 配合条件による摩耗量の差異を明確にする目 的からクロスチェーン (JIS G 3505 SWRM12)を用い た。 また, 同便覧法では, 摩耗量の測定に凹凸測定 装置を用いるとしているが，クロスチェーンを用い 
表-2.2 実験項目と方法

\begin{tabular}{|c|c|c|}
\hline 颔 目 & 方 & 增 \\
\hline 虺度恃性 & 曲げ或酸 & 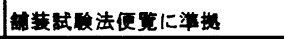 \\
\hline \multirow{3}{*}{ 酎久性 } & ホイールトラッキング或尉 & $"$ \\
\hline & 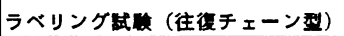 & 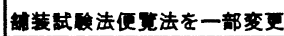 \\
\hline & 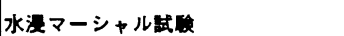 & 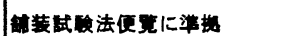 \\
\hline \multirow{2}{*}{ 表面性状 } & 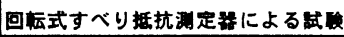 & 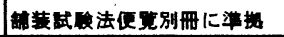 \\
\hline & 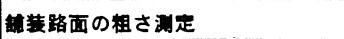 & 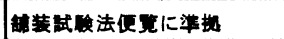 \\
\hline
\end{tabular}

表-2.3 実験に用いた混合物の配合

\begin{tabular}{|c|c|c|c|c|c|c|}
\hline \multirow{2}{*}{ Am } & \multirow{2}{*}{ Ap } & \multicolumn{5}{|c|}{ 買量配合率 (\%) } \\
\hline & & 6 号 & & 租目 & 石秎 & AS \\
\hline 1.0 & \multirow{5}{*}{0.5} & 47.8 & $\overline{23.3}$ & 25.6 & 7.8 & 1.5 \\
\hline 1.5 & & 41.7 & 20.4 & 33.5 & 2.4 & 2.0 \\
\hline 2.0 & & 37.0 & 18.1 & 39.7 & 2.8 & 2.4 \\
\hline 2.5 & & $\overline{33.3}$ & 16.2 & 44.6 & 3.2 & 2.7 \\
\hline 3.0 & & 30.2 & 14.8 & 48.6 & 3.5 & 2.9 \\
\hline 1.0 & \multirow{5}{*}{1.0} & 46.2 & 22.6 & 24.8 & 3.5 & 2.9 \\
\hline 1.5 & & 40.0 & 19.5 & 32.1 & 4.6 & 3.8 \\
\hline 2.0 & & 35.2 & 17.2 & 37.7 & 5.4 & 4.5 \\
\hline 2.5 & & 31.5 & 15.3 & 42.2 & 6.0 & 5.0 \\
\hline 3.0 & & 28.5 & 13.9 & 45.7 & 6.5 & 5.4 \\
\hline 1.0 & \multirow{5}{*}{1.5} & 46.9 & 22.9 & 21.7 & 4.6 & 3.9 \\
\hline 1.5 & & 40.7 & 19.9 & 28.3 & 6.1 & 5.0 \\
\hline 2.0 & & 36.0 & 17.6 & 33.4 & 7.1 & 5.9 \\
\hline 2.5 & & 32,2 & 15.7 & 37.4 & 8.0 & 6.7 \\
\hline 3.0 & & 29.2 & 14.3 & 40.6 & 8.7 & 7.2 \\
\hline 1.0 & \multirow{5}{*}{2.0} & 47.4 & 23.1 & 19.4 & 5.5 & 4.6 \\
\hline 1.5 & & 41.3 & 20.2 & 25.3 & 7.2 & 6.0 \\
\hline 2.0 & & 36.6 & 17.9 & 29.9 & 8.5 & 7.1 \\
\hline 2.5 & & 32.8 & 16.0 & 33.6 & 9.6 & 8.0 \\
\hline 3.0 & & 29.8 & 14.6 & 36.5 & 10.4 & 8.7 \\
\hline 1.0 & \multirow{5}{*}{ 2. 5} & 47.8 & 23.3 & 17.5 & 6.2 & 5.2 \\
\hline 1.5 & & 41.7 & 20.4 & 22.9 & 8.2 & 6.8 \\
\hline 2.0 & & 37.1 & 18.1 & 27.1 & 9.7 & 8.0 \\
\hline 2.5 & & 33.3 & 16.3 & 30.5 & 10.9 & 9.0 \\
\hline 3.0 & & 30.3 & 14.8 & 33.2 & 11.8 & 9.9 \\
\hline
\end{tabular}

た場合では摩耗量が極端に大きくなってこの方法に よる測定が困難である場合が生じるため供試体の重 量損失率によって摩耗特性を評価した。

\section{3. 実験結果と考察}

（1）6号，7号砕石の最密充填配合之各骨材の密度 6 号および 7 号砕石の最密充填配合に関する実験 結果を図一 3.1 に示す. 図は 6 号砕石率が $67.2 \%$ (容 積百分率）で骨材間隙比が最小となることを示して おり, このとき 6 号砕石が構成する骨材間隙に 7 号 砕石が最も効率よく組み込まれているのがわかる. また, 最密充填状態における合成された粗骨材と細 骨材およびフィラービチューメンの密度は表 -3.1 に示すとおりとなった。
表-3.1 骨材とフィラービチューメンの密度

\begin{tabular}{|c|c|c|c|c|}
\hline & 粗骨材 & \multirow{2}{*}{ 細骨材 } & \multicolumn{2}{|c|}{ フィラービチューメン } \\
\hline & 6 号碎石 7 号碎石 & & フィラー & バインダ \\
\hline 密度 $\left(\mathrm{g} / \mathrm{cm}^{3}\right)$ & 1.799 & 1.978 & & \\
\hline 骨材间膫比 & 0.523 & 0.452 & & \\
\hline
\end{tabular}

表-3.2 密粒度アスコン(13)の配合

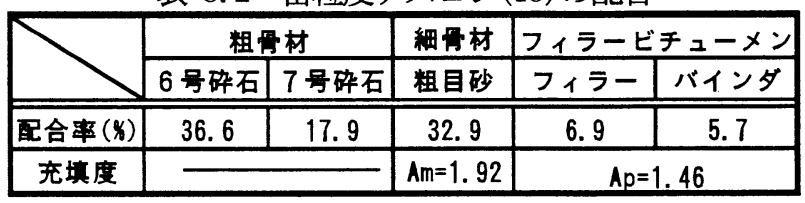

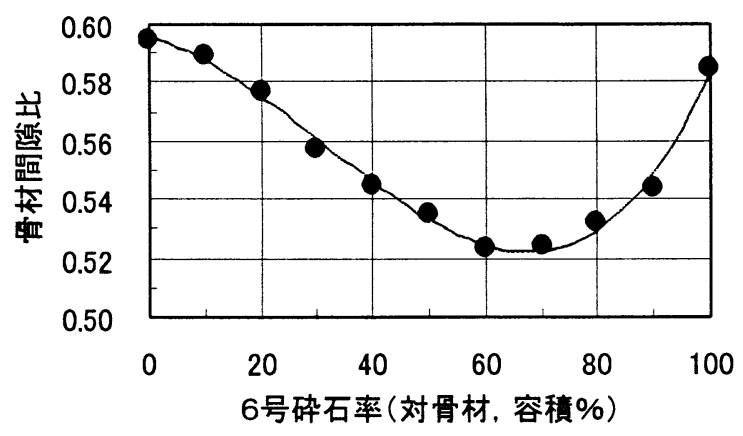

図-3.1 粗骨材の配合と間隙比の変化

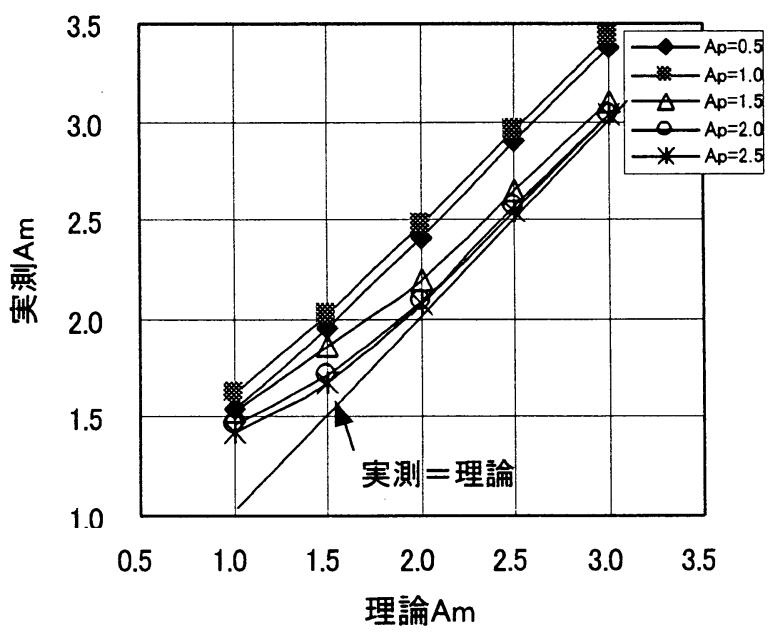

図-3.2 理論Amと害測Amの比較

（2）アスファルト舗装要制による密粒度アスコン (13) の検討

アスファルト舗装要綱に従って密粒度アスコン (13)の配合設計を行った結果，各材料の配合割合は 表-3.2 に示すとおりになった。 また，合成された 最密充填粗骨材と細骨材をそれぞれ単独で締固めた 場合の骨材間隙比とフィラービチューメンの密度か ら, 密粒度アスコン(13)の Am と Ap は, それぞれ 1.92 および 1.46 であることがわかった.

（3）臤合指標 Am，Ap とアスファルト混合物の諸 特性 


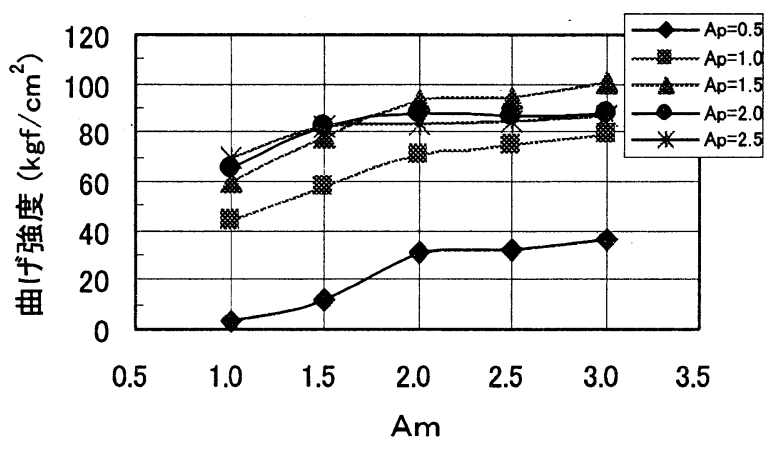

図-3.3 配合指標Amと曲け強度

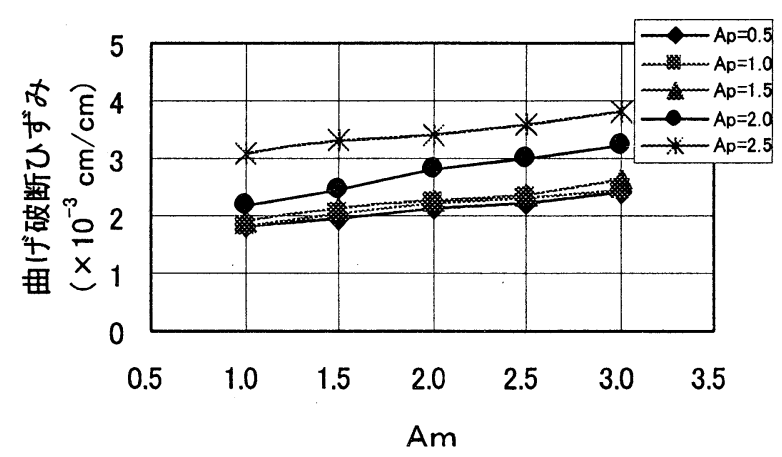

図-3.5 配合指標Amと曲け破断ひずみ

\section{1）締固め特性}

Am および Ap を変化させた混合物の締固め特性 は供試体密度から実測 Am を計算し理論 $\mathrm{Am}$ と比較 することによって把握することができる．結果を図 -3.2に示す. 図より, Ap が1.0より小さい場合, 実測 Am は理論Am より大きくなって混合物が締固 まり難くなっているのがわかる。このとき，実測 A m は理論Am の大きさに関係なく 0.5 程度大きくなる. Ap が1.5より大きい場合, Am が大きくなるにした がって実測 Am は徐々に理論Am に近づき，Amが2.0 より大きくなると, 実測 Am はほぼ理論Amと同じに なって, 粗骨材間隙をアスファルトモルタルが十分 充填していることがわかる.

Ap が小さい場合，混合物が締固まりにくくなる のは粗骨材周囲に付着したモルタルが締固めによる 粗骨材の再配置を妨げるからと考えられ，その抵抗 力はモルタル量よりもモルタルの質，すなわちアス ファルトが少ないことによるモルタルのせん断抵抗 力の増大が大きく影響することが明らかである.Ap が大きい場合, モルタルのせん断抵抗力は小さくな るので Am が大きい場合では締固めによる粗骨材の 再配置は容易となるが，Am が小さい場合では粗骨 材を包み込むモルタル量が不足するので骨材再配置 は不十分になるものと考えられる.したがって，Am, Ap から混合物の締固めを考える場合，細骨材間隙 容積の 1.5 倍程度以上のフィラービチューメンを有

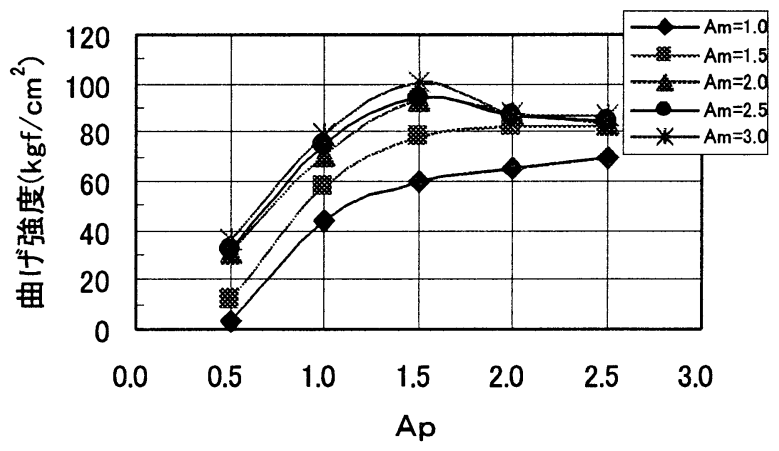

図-3.4 配合指標Apと曲け強度

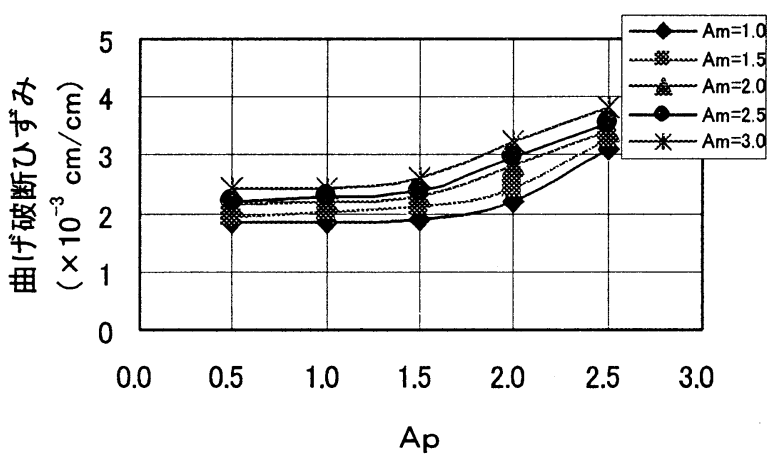

図-3.6 配合指標Apと曲げ破断ひずみ

するモルタルを粗骨材間隙容積の 2.0 倍程度以上用 いた場合に十分な締固めが得られることが明らかと なった。

\section{2）曲げ強度および曲げ破断ひずみ}

$\mathrm{Am}, \mathrm{Ap}$ と曲げ強度の関係を図-3.3と図ー 3.4 に示 す. Am と曲け強度の関係を示した図－3.3によれば, 曲げ強度は Am が大きくなるにしたがって大きくな るが, その増加傾向はある Am の值まで比較的大き く, Am がそれ以上になると緩やかなものとなること が明らかである. 強度の増加傾向が変化する Am は, $\mathrm{Ap}$ が2.0より小さい場合に 2.0 程度となり, Ap が2.0 以上の場合に 1.5 程度となった。次に, Ap と曲げ強 度の関係を示した図ー3.4によれば，曲げ強度は $\mathrm{Ap}$ が1.5程度まで比較的大きく増大するが, Ap が1.5以 上になると Am によって変化傾向が異なることがわ かる. すなわち, Am が2.0より小さい場合, 曲げ強 度は Ap の増加によって緩やかな増加を示すが, Am が2.0以上になると Ap の増加によって次第に減少し, Ap がさらに大きくなると Am に係わらずほぼ一定の 值になることが明らかである.

Am の増加によって曲げ強度が大きくなるのは, モ ルタルによる粗骨材間隙の充填程度が次第に大きく なって載荷によるひび割れが粗骨材と粗骨材の接点 からモルタル部分にも分散されるようになるからと 考えられる. Am が2.0あるいは1.5を超えて増加傾向 が緩やかとなるのは供試体に占めるモルタルの割合 


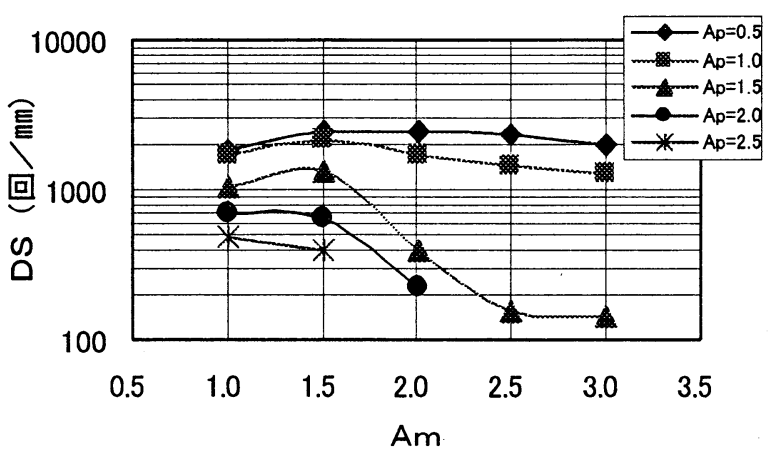

図-3.7 配合指標Amと動的安定度
が大きくなってひび割れが次第にモルタル部分のみ を貫通するようになるからと考えられ，Ap が大きい 混合物では小さい場合に比べて小さな Am で均質な 混合物になるからと考えられる. 次に, Ap が増加す ることによって曲げ強度が増加するのは同じモルタ ル量でもフィラービチューメン量が大きい場合に粗 骨材とモルタルの付着強度が大きくなるからである. Am が2.0以上の場合で Ap が1.5より大きくなると曲 げ強度が低下して一定值に近づくのは，このような 状態の供試体は細粗骨材を包むアスファルトが余㮃 となって厚みを有し, ひび割れが粗骨材とモルタル, 細骨材とフィラービチューメンの境界ばかりでなく アスファルト部分をかなり多く通って発生するから であろうと考えられる。したがって，Am，Ap から混 合物の曲げ強度を考えると, 細骨材間隙の 1.5 倍程度 のフィラービチューメンを有するモルタルを粗骨材 間隙の 2 倍程度配合すると曲げ強度の大きな混合物 が得られることが明らかとなった。これは，1)に示 した混合物の締固め特性で述べたように, Am が2.0 以下，Apが1.5以下となった場合に混合物は締固め難 くなって空隙が残るため，これにしたがって曲げ強 度が急激に小さくなるもので，この Am, Ap の值が 配合設計におけるチェックポイントの一つであると 考えられる。

次に, Am, Ap と曲げ破断ひずみの関係を図 -3.5 と図ー3.6に示す.Am と曲け破断ひずみの関係を示 した図ー3.5によれば，曲げ破断ひずみは Am が増加 するにしたがって増加し，その増加傾向は Ap が変 化してもほとんど変化しないことがわかる.また，A pと曲け破断ひずみの関係を示した図一3.6によれば, 破断ひずみは Ap が増加するにしたがって増加する ものの Ap が1.5程度までは増加傾向がほとんど無く, Ap が1.5を超えると急に増加傾向が著しくなること がわかる.

これらの傾向は, アスファルトモルタルの粗骨材 との付着, 伸び能力および量を考慮すれば分かりや すい. すなわち, Ap が小さく付着力および伸び能力

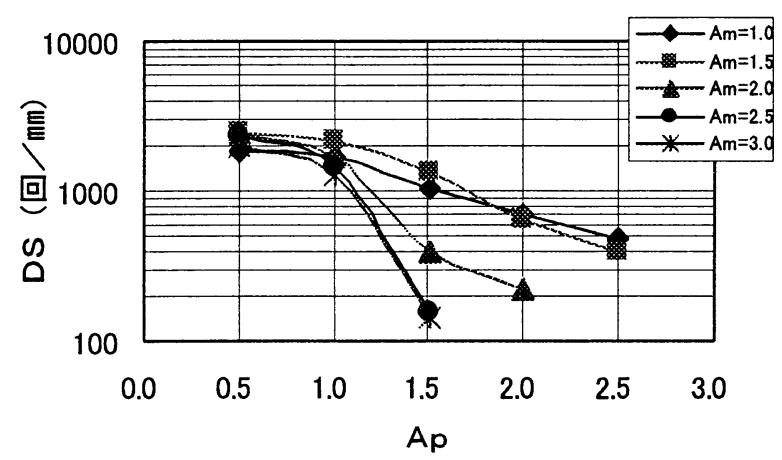

図-3.8 配合指標A と動的安定度

の小さいモルタルを用いても曲げ破断ひずみは大き くならず, Ap が大きくなってフィラービチューメン が多くなるとこれらが改善されてくるものと考えら れる. また, 付着力と伸び能力はフィラービチュー メンによって決まるものの, 破断ひずみの大きさは モルタルの量に比例して增加するものと考えられ，A $\mathrm{p}$ が大きい場合の破断ひずみの変化傾向が Ap の小 さい場合とほぼ同様になったものと考えられる。し たがって，Am，Ap から曲け破断ひずみを考えると， Amはある程度大きくして Ap を 1.5 以上とすると破断 ひずみの大きい混合物が得られることが明らかとな った.

\section{3）硬流動性}

$\mathrm{Am}, \mathrm{Ap}$ 動的安定度の関係を図-3.7と図-3.8に示 す. 図中で一部データが欠落しているが, これは， 3 $0 \mathrm{~mm}$ 以上のわだちが生じた場合にデータを無効とした からである.Am と動的安定度の関係を示した図ー3. 7によれば, 動的安定度は, Ap が1.0より小さい場合, $\mathrm{Am}$ の増加によって若干の減少傾向を示すがその傾向 はあまり大きくなく, Ap が1.0以上の場合, Am が1. 5を超えると急激に低下することが明らかである．ま た，Ap と動的安定度の関係を示した図ー3.8によれ ば, 動的安定度は Ap が1.0を超えると急激に低下し, 特に, Am が2.0以上になるとその傾向が著しいこと がわかる.これらの結果は, 粗骨材間隙に対するモ ルタル量が大きい場合や細骨材間隙に対するフィラ 一ビチューメン量が大きい場合, 外部荷重の作用に よる細粗骨材の再配置が容易になるからであり，1) で示した締固めにおける考察と同様に，骨材周囲の モルタルあるいはフィラービチューメンが骨材再配 置に大きく影響する結果であると考えられる. また, この傾向はアスファルトモルタル量, フィラービチ ユーメン量が大きくなると変形が大きくなるという 従来の結果と同様であるが, アスファルトモルタル を粗骨材間隙容積の1.5倍以下とすると動的安定度が 大きいこと, モルタル量が粗骨材間隙容積の 1.5 以上 の場合でもフィラービチューメン量を細骨材間隙容 


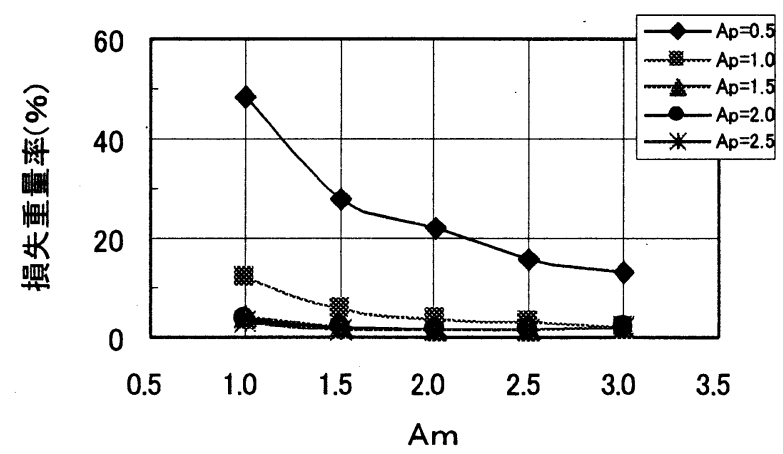

図-3.9 配合指標Amと摩耗損失重量

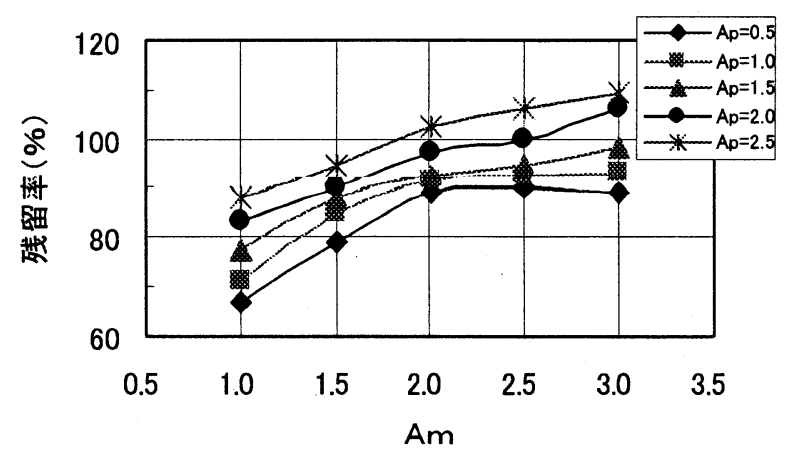

図-3.11 配合指標Amと安定度残留率

積の 1.0 倍以下とすることによって動的安定度が改善 されることが明らかとなった.これは, 空隙率 3〜6\%, 飽和度70 85\%などの従来の混合物基準と異なって 混合物を把握する上で分かりやすい配合指標である と言える。

\section{4）耐摩耗性}

$\mathrm{Am}, \mathrm{Ap}$ と摩耗量の関係を図-3.9と図-3.10に示す. これらの図より，混合物の摩耗量は Am が増加する にしたがって，また，Ap が増加するにしたがって小 さくなることがわかる．また，摩耗量の変化傾向は $\mathrm{Am}$ が1.5より大きく, Ap が1.0より大きくなると著 しく小さくなることが明らかである.これらの傾向 は, Am, Ap が大きくなると混合物のアスファルトモ ルタルおよびフィラービチューメンが多くなって締 固めが充分行われると同時に粗骨材がフィラービチ ユーメンを多く有するアスファルトモルタルに包ま れるようになるので飛散し難くなることによる．Am, Ap から耐摩耗性を考えると, アスファルトモルタル 量を粗骨材間隙容積の1.5倍以上にすると効果的であ り，モルタル量が1.5倍以下の場合でもフィラービチ ユーメン量を細骨材間隙容積の 1.0 倍以上とすると摩 耗抵抗性を大きく改善できる.

\section{5）涌水性}

$\mathrm{Am}, \mathrm{Ap}$ と残留安定度の関係を図-3.11 と図-3.12 に示す.Am と残留安定度の関係を示した図 -3.11 によれば, 残留安定度は, Am の増加にしたがって

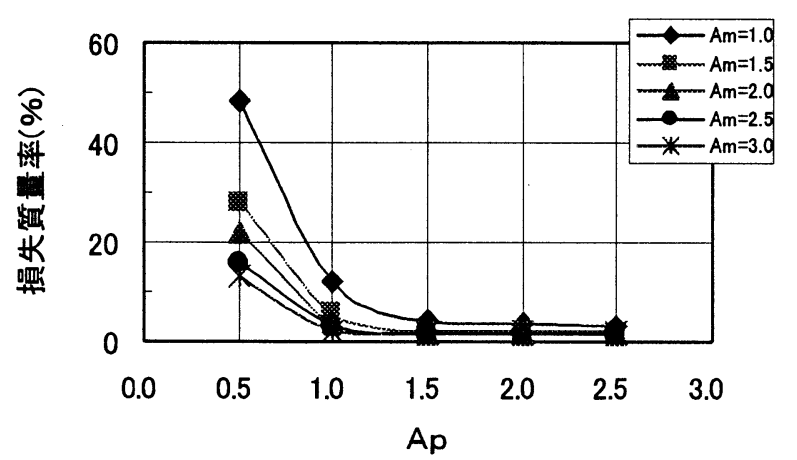

図-3.10 配合指標Apと摩耗損失重量

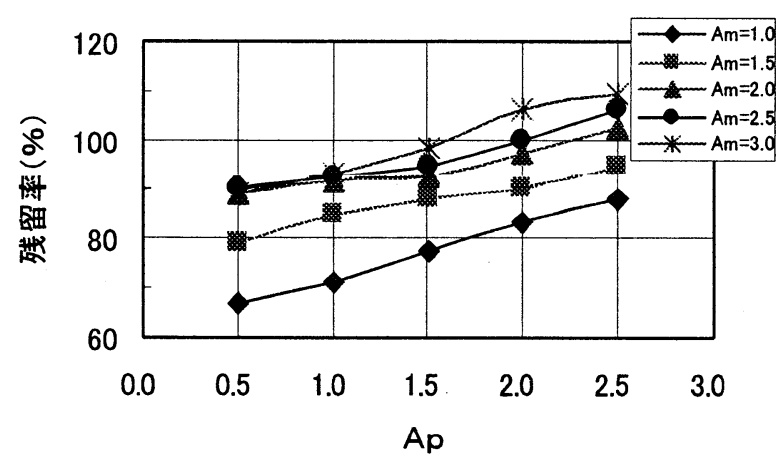

図-3.12 配合指標Apと安定度残留率

增加するが, Ap が 1.5 より小さい場合では, Am が 2.0 を超えるとほほ一定の值を示し, Ap が 1.5 以 上の場合では, Am が 2.0 を超えても増加傾向を保 つのがわかる. また, Ap と残留安定度の関係を示 した図ー3.12 によれば, 残留安定度は Ap の增加 にともなって増加するが, Am が 2.0 以上で Ap が 1.5 以下の場合にほとんど変化しないことがわかる. Am が大きくなることによる残留安定度の増加は, アス ファルトモルタルが粗骨材間隙を満たして混合物の 水密性を大きくし, 粗骨材に皮膜したアスファルト の剥離が小さくなるからと考えられる。 また, Am が 2.0 を越え Ap が 1.5 以下の場合に残留安定度が ほとんど変化しないのは, この範囲のモルタルの剥 離抵抗があまり大きくなく残留安定度がモルタル量 に支配されないことによると考えられる。Ap によ る残留安定度の增加は細骨材の空隙をフィラービチ ユーメンが充填するからで, それにともなって水密 性の向上とアスファルトの剥離抵抗性が向上するか らである.したがって, Am, Ap から混合物の耐水 性を考えると, 粗骨材間隙容積の 2.0 倍程度以上の モルタル量と細骨材間隙容積の 1.5 倍程度のフィラ 一ビチューメン量とすることにより水密性, 耐水性 を向上することが可能になると思われる.

\section{6）滑り抵抗性}

$\mathrm{Am}, \mathrm{Ap}$ と速度 $60 \mathrm{~km} / \mathrm{hr}$ における供試体の摩擦係 数の関係を図 -3.13 と図-3.14 に示す. Am と摩擦係 


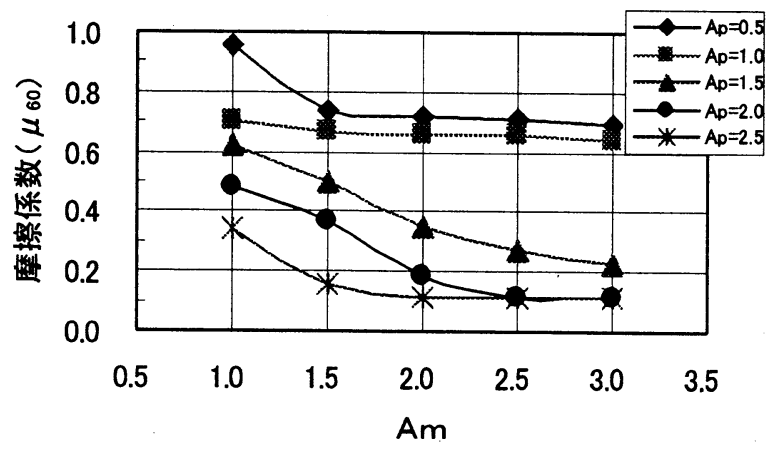

図-3.13 配合指標Amと摩擦係数

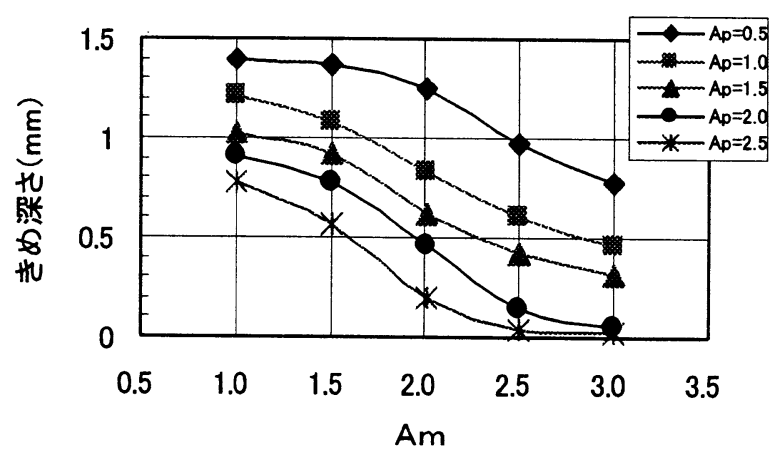

図-3.15 配合指標Amと路面きめ粗さ

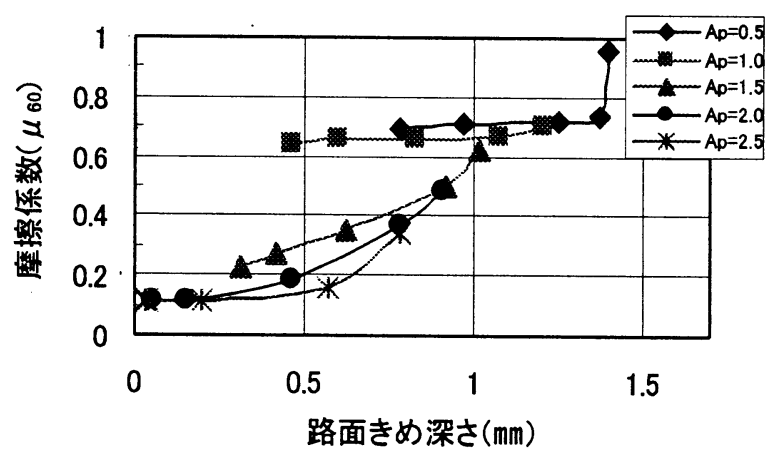

図-3.17 路面きめ深さと摩擦係数

数の関係を示した図ー3.13によれば，摩擦係数は, $\mathrm{Am}$ の増加にともなって小さくなり, その変化は Ap が 1.0 より大きくなると著しくなることがわかる.ま た，Ap と摩擦係数の関係を示した図ー3.14によれ ば，摩擦係数は Ap の増加に伴ってほぼ直線的に減 少することが明らかである.これらの傾向は, 粗骨 材間隙をモルタルが充填し，細骨材の間隙をフィラ ービチューメンが充填することによるが, Ap が 1.0 以下の場合，粗骨材間隙へフィラービチューメンで 充分被膜されていない細骨材が満たされることにな るので摩擦係数は大きく低下せず, Ap が 1.0 以上 の場合, 細骨材はフィラービチューメンで充分被膜 されるようになるので摩擦係数の減少は大きくなる. また, Am と Ap が増加することは供試体のマクロ テクスチャーが滅少することとなり，これも滑り摩 擦係数を減少させる原因となる。これについては表

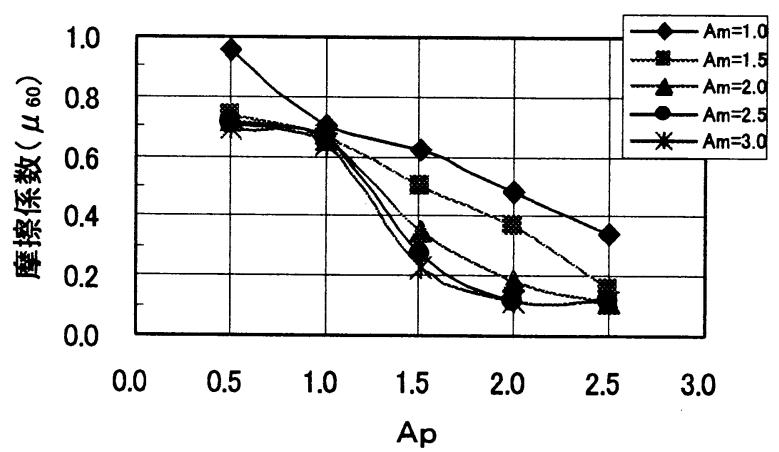

図-3.14 配合指標Apと摩擦係数

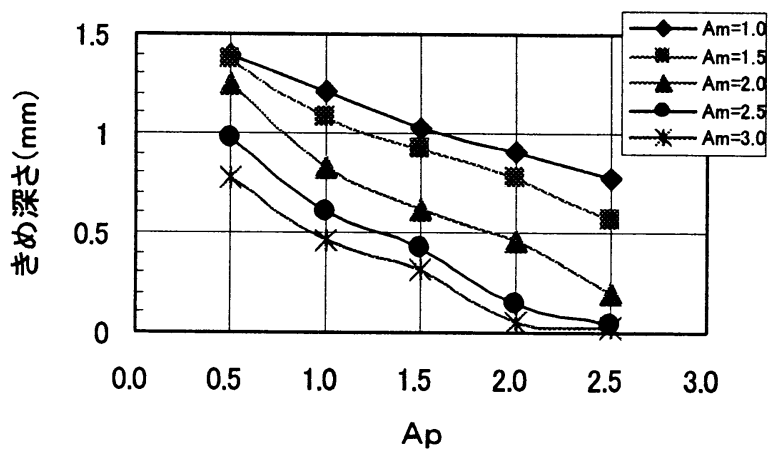

図-3.16 配合指標Apと路面きめ粗さ

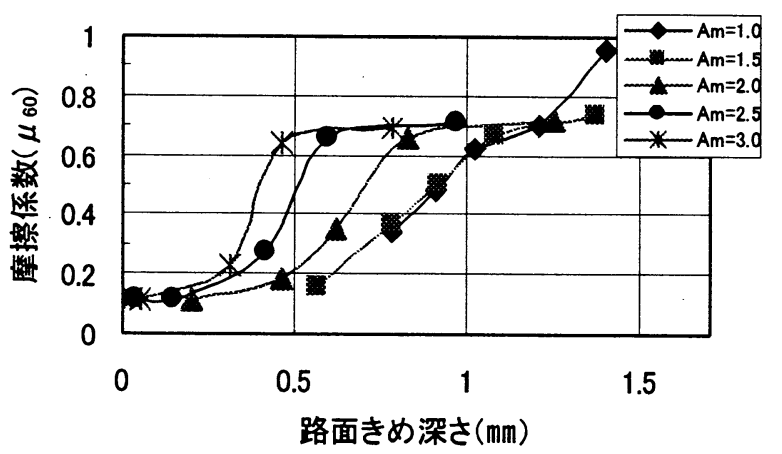

図-3.18 路面きめ深さと摩擦係数

面きめ深さの項で再度考察する.したがって, Am, Ap より混合物の滑り抵抗性を考えた場合, フィラ 一ビチューメンを細骨材間隙容積の 1.0 倍以下とす ることにより摩擦係数の低下を抑制することが可能 であると考えられる。

\section{7）表面のきめ深さ}

$\mathrm{Am}, \mathrm{Ap}$ と路面きめ深さの関係を図-3.15 と図-3.16 に, また, 路面きめ深さと摩擦係数の関係を図-3.17 と図-3.18 に示す. Am, Ap ときめ深さの関係を示 した図-3.15 図-3.16によれば，路面きめ深さは，Am と Ap が増加するにともなって小さくなるが, Ap が 小さいモルタルを使用した場合では Am を大きくし ないときめ深さが小さくならないことがわかる．ま た，きめ深さに対する Ap の影響は大きいことも明 らかである.これらのことは, Am, Ap が混合物の 締固めに及ほす影響と粗骨材間隙に対するモルタル 
量と細骨材間隙に対するフィラービチューメン量を 表していることを考慮すれば明らかで，Am，Ap が 大きいほど混合物は良く締固めることができ，かつ， 平坦に仕上げることが出来るからである，また，き め深さと摩擦係数の関係を示した図-3.17 と図-3.18 によれば, 供試体のきめ深さが同じであっても Am, Ap によって摩擦係数が異なりることがわかる。し たがって, Am, Ap から摩擦係数も考慮してきめ深 さを考えると, Am は 2.0 以上とし, Ap を 1.0 以下 とすれば，摩擦係数を低下させることなくきめ深さ を小さくすることができるものと考えられる.

\section{4. 結論}

本研究において, 配合指標 $\mathrm{Am}, \mathrm{Ap}$ を定義し,こ れがアスファルト混合物の特性の変化を示すことが できるか否か検討した。本実験の範囲で得られた結 論を以下に示す.

（1）配合因子 Am および Ap は，舗装用アスファルト 混合物の特徴を表す各試験項目において，いずれも その変化傾向を適切に示していた.

（2） Am，Ap は物理的意味を有しており，これを用 いることにより舗装用アスファルト混合物の配合設 計を合理的に行うことが可能と考えられる.
（3）配合指標 $\mathrm{Am}, \mathrm{Ap}$ を用いて密粒度アスコン(13) を検討した結果, Am と Ap はそれぞれ 2.0 と 1.0 程 度が適切であると判断される. 同混合物をアスファ ルト舗装要網法で設計した場合の配合は, Am と Ap がそれぞれ 2.0 と 1.5 程度となり, 前者の場合と若 干差がある結果となった。

\section{参考文献}

1）(社）日本道路協会 : アスファルト舗装要綱，pp.90-99, 1992

2）（社）日本道路協会 : アスファルト舗装要綱，pp. 46-55, 1961

3）松野三郎 : 加熱アスファルト混合物の配合設計と施工 に関する研究, 1976

4) 南雲貞夫, 成田保三 : アスファルト舗装要綱（昭和 50 年版)について, 舗装, Vol.11, No.5, pp. 3-10, 1976

5)たとえば，建設図書 : 舗装技術の質疑応答，第一巻, pp. 56-57, 1972

6) 小山道義:寒冷地におけるアスフアルト舗装用合材の配 合設計方法に関する一つの試み，アスファルト，第 5 巻, 第 25 号, pp. 2-8,pp. 30, 1962

7）（社）日本道路協会 : 転圧コンクリート舗装技術指針 (案)，1990

\section{STUDY ON DESIGN FACTOR OF ASPHALT MIXTURE CONSIDERING AGGREGATE VOIDS}

\section{Koichi OZAWA, Shuichi KOKUBUN and Masashi KOYANAGAWA}

It is well known that characteristics of asphalt mixture are influenced by quantity of asphalt mortar and filler bitumen. The use of the special mixture increases at present as much as the continuously graded mixture. The method of mix design described in the MANUAL FOR ASPHALT PAVEMENT may have a limit to apply for all types of asphalt mixture. Therefore, it is necessary to consider the asphalt mortar and filler bitumen more than present mix design method. In this study, the ratio of asphalt mortar volume to coarse aggregate void volume and the ratio of filler bitumen volume to fine aggregate void volume are defined as design factors, and it is examined that these design factors would be able to express the tendency of characteristics of the dense asphalt mixture. 